\title{
Bioactivity of Clove (Syzygium aromaticum) against Some Taxa of Enterobacteriaceae Isolated from Fresh Ground Beef
}

\author{
Abdel-Hamied M. Rasmey ${ }^{\#}$ and Fatma Mahran \\ Department of Botany and Microbiology, Faculty of Science, Suez University, Suez, \\ Egypt.
}

\begin{abstract}
NVESTIGATION of antibacterial activity of some spices against some enteric bacterial species isolated from fresh ground beef was the aim of this study as well as the identification of the active metabolites of the selected active spice. A number of morphologically varied 90 enteric bacterial isolates were recovered on MacConkey agar from 20 fresh ground beef (cows) samples collected from butcher shops located at Suez City, Egypt. The collected 90 bacterial isolates were characterized into six groups based on their phenotypic characteristics according to Bergey's manual and were identified genetically using $16 \mathrm{~S}$ rRNA gene sequencing to Serratia nematodiphila, Proteus penneri, Enterobacter cloacea, Shigella sonnei, Providencia rettgeri and Escherichia fergusonii and deposited in GenBank with accession numbers KY712436, KY712438, KY712439, KY712440, KY712441 and KY712442, respectively. The aqueous extracts of seven spices: Cloves, thyme, cinnamon, ginger, anise, red pepper and curry were tested for their antibacterial activity against the isolated bacteria and the obtained results indicated that clove extract was the most active antibacterial among the other tested spices. The GC-MS analysis of the clove extract metabolites revealed that the active compound was the eugenol.
\end{abstract}

Keywords: Antibacterial, Enterobacteriaceae, Clove, Eugenol, Beef.

\section{Introduction}

The consumption of meat contaminated by foodborne pathogens leads to foodborne diseases and represent a huge public health problem nowadays in the developing countries (Kiessling, et al., 2002; Adwan et al., 2015 and Rasmey et al., 2018). It has been reported that about $50 \%$ of the foodborne illness cases every year in the developing countries are due to contaminated meat and poultry (Ahmed \& Sarangi, 2013). Meat is a suitable nutritional medium for microorganisms due to its high content of moisture, nitrogenous compounds, minerals and growth factors (Thanigaivel \& Anandhan, 2015). There are various infectious agents responsible for these diseases, but the most predominant bacterial species were related to the family Enterobacteriaceae (Addis \& Sisay, 2015). A major concern in food hygiene is the contamination of meat with Salmonella, Shigella, Escherichia, Proteus and Klebsiella species that originate from the raw meat or through processing and storage (Paterson, 2006 and
Gwida et al., 2014). In addition to the diseases caused by these bacteria, they are responsible for meat spoilage and lead to large economic losses. Their metabolic activity of the meat leads to the change of odor, color, taste, texture defects and nutritional value and have therefore a negative impact on the poultry meat production (Höll et al., 2016). Therefore, the effective preservatives must be used to inhibit or reduce the contamination of meat products by bacteria during storage.

There are various chemical preservatives such as nitrates, nitrites and benzoates salts were widely added to the food products to inhibit the growth and survival of food pathogens during storage (Sharma, 2015 and Zhao et al., 2017). However, the uses of chemical preservatives and antibiotics in food over the last years leds into the development of resistant bacterial strains. Such practice is unacceptable manner due to their side effects on human health (Karlowsky et al., 2003 and Chikwendu et al., 2008). Also, it has been reported that the preservation of food by high salt content may increase the hypertension

"Corresponding author email: am_rasmey@yahoo.com DOI: $10.21608 /$ ejm.2018.5398.1074

C2018 National Information and Documentation Center (NIDOC) 
and risk of cardiovascular disease (Desmond, 2006). This increases the demand for high quality and minimally processed food products with prolonged shelf-life, free from or with small quantities of added chemical antimicrobial agents (Sharma, 2015). So, using of natural compounds such as herbs extracts and spices has been received more attention as an alternative to the chemical additives (Tajkarimi et al., 2010).

Herbal spices have been used as food additives as natural flavouring agents since ancient times. Over the last years, various studies reported the antimicrobial activity of spices against the foodborne pathogens. Several spices, such as clove, cinnamon, garlic, ginger, allspice, caraway, cumin, oregano, rosemary, sage and thyme, have been reported to have significant antimicrobial activities (Burt, 2004; Kwon et al., 2008 and Gutierrez et al., 2009). The flavor and antibacterial properties of the spices are related to the presence of alkaloids, phenolics, flavonoids, anthocyanins, glycosides, steroids, essential oils, coumarins and tannins (Gottardi et al., 2016).

The main goal of the present study was to evaluate the occurrence and frequency of Enterobacteriaceae in the fresh ground beef as well as to determine the antibacterial activity of some spices against the isolated foodborne pathogens. Also, the elucidation of the active compounds of the most potent spice was addressed.

\section{Materials and Methods}

\section{Collection of samples}

Twenty fresh ground beef (cows) samples were randomly purchased from different butchershops located at Suez City, Egypt. The samples were collected in sterilized polyethylene bags and transferred under aseptic conditions to the laboratory to be analyzed during one hour of collection.

\section{Isolation and enumeration of bacteria}

Nutrient agar (NA) and MacConkey agar (MAC) media were used to isolate and count of the contaminated bacteria in the collected ground beef samples. Twenty five grams of each sample were homogenized in $225 \mathrm{ml}$ of the sterile buffered peptone water and incubated at $37^{\circ} \mathrm{C}$ for 1h. Ten $\mathrm{ml}$ of this suspension were immediately drawn into $90 \mathrm{ml}$ sterile buffered peptone water and serially diluted to $10^{-5}$. By using pour plate method, $1 \mathrm{ml}$ of each dilution was transferred aseptically into each plate and incubated at $37^{\circ} \mathrm{C}$ for $48 \mathrm{~h}$. The developed colonies were counted and those of morphological variations were picked up and sub-cultured onto fresh agar medium. The bacterial cultures were purified and transferred onto tryptic soya agar (TSA) slants and preserved at $4^{\circ} \mathrm{C}$.

\section{Characterization and identification of the isolated bacteria \\ Phenotypic characterization}

The colour, shape, surface, margin, elevation and opacity of the bacterial colony were recorded on MAC agar medium. The shape of microscopic cells was examined after Gram staining. Also, the isolated bacteria were subjected to physiological and biochemical tests such as oxidase, catalase production, urease, indole, starch hydrolysis, gelatin liquefaction, methyl red (MR), VogesProskauer (VP), glucose and lactose fermentation according to Bergey's Manual of Determinative Bacteriology.

\section{Genotypic characterization}

DNA extraction: The pellets of vegetative cells were collected by centrifugation at $5000 \mathrm{rpm}$ for $20 \mathrm{~min}$ and vortexed vigorously for $1 \mathrm{~min}$ after adding of $300 \mu \mathrm{l}$ lysis buffer and $2 \mu \mathrm{l}$ RNAase A. Then $8 \mu \mathrm{l}$ of proteinase $\mathrm{K}$ was added to the mixture and mixed, incubated at $60^{\circ} \mathrm{C}$ for $10 \mathrm{~min}$, cooled down for $5 \mathrm{~min}$. Three hundred $\mu$ l binding buffer were added and centrifuged for $5 \mathrm{~min}$ at $10,000 \mathrm{~g}$. After that the lysate was pipetted directly into the spin column and the flow was discarded after centrifugation for $1 \mathrm{~min}$ at $10,000 \mathrm{~g}$. Then $500 \mu \mathrm{l}$ washing buffer was added into spin column, centrifuged for $30 \mathrm{sec}$ at $10,000 \mathrm{~g}$ and the flow through was discarded and this step was repeated again. To remove residual washing buffer, they were centrifuged again at $10,000 \mathrm{~g}$ for $1 \mathrm{~min}$. Finally, the columns were filled with $40-50 \mu$ l elution buffer, incubated at room temperature for $1 \mathrm{~min}$, centrifuged at $10,000 \mathrm{~g}$ for $2 \mathrm{~min}$ and DNA was stored at $-20^{\circ} \mathrm{C}$.

PCR amplification: The PCR amplification was performed by using Qiagen Proofstart Tag Polymerase kit (Qiagen, Hilden, Germany). The primers (16SF: 5'-GAGTTTGATCCTGGCTTAG-3' and 16SR: 5'-GGTTACCTTGTTACGACTT-3') were used. Two $\mu \mathrm{l}$ of template DNA $(20 \mathrm{ng} / \mu \mathrm{l}), 12.5 \mu \mathrm{l}$ PCR master mix, 20pmol $(2 \mu \mathrm{l})$ each of forward and 
reverse primers and $8.5 \mu \mathrm{l}$ of water DNAase free water were added together to complete the reaction volume to $25 \mu$. Then the complete reaction mixture was incubated at automated thermo-cycler TC-3000 (Biotechnology Research Center, Suez Canal University, Ismailia). The mixture was denaturated at $94^{\circ} \mathrm{C}$ for $5 \mathrm{~min}$, then 37 cycles of denaturation were done at $94^{\circ} \mathrm{C}$ for $30 \mathrm{sec}$, then the mixture was annealed at $51^{\circ} \mathrm{C}$ for $30 \mathrm{sec}$ and then an extension was done at $72^{\circ} \mathrm{C}$ for $30 \mathrm{sec}$. At last, a final extension was conducted at $72^{\circ} \mathrm{C}$ for $5 \mathrm{~min}$. The products of PCR were analyzed by electrophoresis on $1.5 \%(\mathrm{w} / \mathrm{v})$ agarose in $1 \mathrm{X}$ TAE buffer and gels. The photos were captured by gel documentation system and analyzed by Gel Docu advanced ver.2 software. The PCR products of $1500 \mathrm{bp}$ were purified from the gel with QIA quick gel extraction kit (Qiagen, Hilden, Germany).

DNA sequencing: The purified PCR products were cycle sequenced with didesoxy mediated chain-termination (Sanger et al., 1977). The sequences were analyzed and assembled to assess the degree of DNA similarity using BLAST search program at the NCBI website: http:// www. ncbi.nlm.nih.gov/BLAST/ and CLUSTALW program (http://clustalw.ddbj.nig.ac.jp/topehtml). Phylogenetic trees of the 16S rRNA gene sequences of the unknown bacteria with the related 16S rRNA gene sequences from different standard bacteria strains obtained from GenBank were displayed by the TREE VIEW program.

Nucleotide sequence accession numbers: The nucleotide sequences of the isolates number 2006, 2051, 2059, 2103, 2115 and 2434 were deposited in the GenBank database with accession numbers KY712436, KY712438, KY712439, KY712440, KY712441 and KY712442, respectively.

\section{Spices extract preparation}

Seven dry spices: Clove (Syzygium aromaticum), thyme (Thymus vulgaris), cinnamon (Cinnamomum verum), ginger (Zingiber officinale), anise (Pimpinella anisum), red pepper (Capsicum annuam) and curry (Murraya koenigii) were obtained from local markets in Suez City, Egypt. Fifty grams of each spice were mixed with $200 \mathrm{ml}$ distilled water and shaking at $140 \mathrm{rpm}$ for 24h. The extracts were filtered through a fine mesh cloth, centrifuged at 4000rpm for $20 \mathrm{~min}$, and evaporated under vacuum and stored at $4^{\circ} \mathrm{C}$.
Determination of the antibacterial activity of the spices extract

The antibacterial activity of the aqueous extracts of the spices was performed by the well diffusion method. A $100 \mu 1$ of each extract were injected intoan agar well of plates previously seeded with the tested bacterial isolate. The plates were left for $1 \mathrm{~h}$ in a refrigerator, then incubated at $37^{\circ} \mathrm{C}$ for $24 \mathrm{~h}$ and were examined and the diameter of inhibition zones were recorded (Sethi et al., 2013). Also, the chloroform, ethanol, acetone and ethyl acetate extracts of clove were prepared by the same method and tested for their antibacterial activity against the isolated bacteria.

The minimum inhibitory concentration (MIC) of aqueous, chloroform, ethanol, acetone and ethyl acetate extracts of clove against the isolated enteric species was determined by testing different concentrations $(1-750 \mathrm{mg} / \mathrm{ml})$ using the well diffusion method.

Gas chromatography-mass spectrometry (GC-MS) analysis of the ethyl acetate extract of clove

The GC-Ms analysis of the clove ethyl acetate extract was carried out using gas chromatographymass spectrometry instrument stands at the Central Laboratory, National Research Center, Egypt with the following specifications. Instrument, a TRACE GC Ultra Gas Chromatographs (THERMO Scientific Corp., USA), coupled with a THERMO mass spectrometer detector (ISQ Single Quadrupole Mass Spectrometer). The GC-MS system was equipped with a TG-5MS column $(30 \mathrm{~m} \times 0.32 \mathrm{~mm}$ i.d., $0.25 \mu \mathrm{m}$ film thickness). Analyses were carried out using helium as the carrier gas at a flow rate of $1.0 \mathrm{ml} / \mathrm{min}$. The following temperature program: $50^{\circ} \mathrm{C}$ for $1 \mathrm{~min}$, rising at $5^{\circ} \mathrm{C} / \mathrm{min}$ to $280^{\circ} \mathrm{C}$ and held for $5 \mathrm{~min}$. The injector and detector were held at 220 and $200^{\circ} \mathrm{C}$, respectively. Diluted samples (1:10 Diethyl ether, $\mathrm{v} / \mathrm{v}$ ) of $1 \mu \mathrm{L}$ of the mixtures were always injected. Mass spectra were obtained by electron ionization (EI) at $70 \mathrm{eV}$, using a spectral

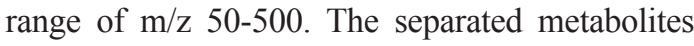
were identified by comparing with NIST mass spectral library data.

\section{$\underline{\text { Results and Disscusion }}$}

Isolation and enumeration of Enterobacteriaceae

Ninety bacterial isolates belonging to the family Enterobacteriaceae were recovered on MAC agar medium from 20 ground beef samples. All the isolated bacteria were Gram negative, rod 
shaped cells and non spore former. Various studies have shown the importance of the constituents of MAC medium as a selective medium for Enterobacteriaceae due to the presence of crystal violet and bile salts which inhibit the growth of Gram positive bacteria and also the presence of lactose sugar differentiate between the lactose fermentable and non-fermentable Gram negative bacteria (Joosten, et al., 2008; Becker et al., 2009 and Doulgeraki et al., 2011). According to the morphological characters of the colonies such as color, shape, margin, elevation and texture, the recovered bacterial isolates were divided into six groups (I, II, III, IV, V and VI) as presentedintable 1. The colonies of the bacterial isolatesof groups II, III and VI were colorless on MAC agar which indicates that they are non-lactose fermenter. On the other hand the members of bacterial groups I, IV and V were lactose fermenter and appeared as pink or red colonies. Also, the biochemical characteristics of all groups such as fermentation of glucose, indole, methyl red, Voges-Proskauer, citrate (IMViC) tests, $\mathrm{H}_{2} \mathrm{~S}$ production, urease, catalase production, oxidase production and other tests were studied and the obtained results revealed that all isolated bacteria belong to the family Enterobacteriaceae (Table 1). Based on the morphological and biochemical characteristics, the bacterial groups I, II, III, IV, V and VI were identified at the genus level as Enterobacter, Providencia, Proteus, Serratia, Esherichia and Shigella spp., respectively. For identification of the isolated bacteria at the species level, one isolate from each group was selected and their DNA was extracted and PCR amplified (Fig. 1). The resulted PCR products were subjected to $16 \mathrm{~S}$ rRNA gene sequencing and were compared to 16S rRNA gene sequences of GenBank database using BLAST search analysis. The isolates no. 2059 (I), 2115 (II), 2051 (III), 2006 (IV), 2434 (V), and 2103(VI) were identified as Enterobacter cloacea, Providencia rettgeri, Proteus penneri, Serratia nematodiphila, Escherichia fergusonii, and Shigella sonnei, respectively. The phylogenetic tree of their positions among the related bacterial species was inferred from 16S rRNA sequence data by the neighbor-joining method (Fig. 2). The diversity of microbial population has been reported by many studies dealing with meat (Ercolini et al., 2006; Joosten et al., 2008; Becker et al., 2009; Doulgeraki et al., 2011 and Rasmey et al., 2018).

TABLE 1. Morphological and biochemical characterization of the isolated bacterial groups.

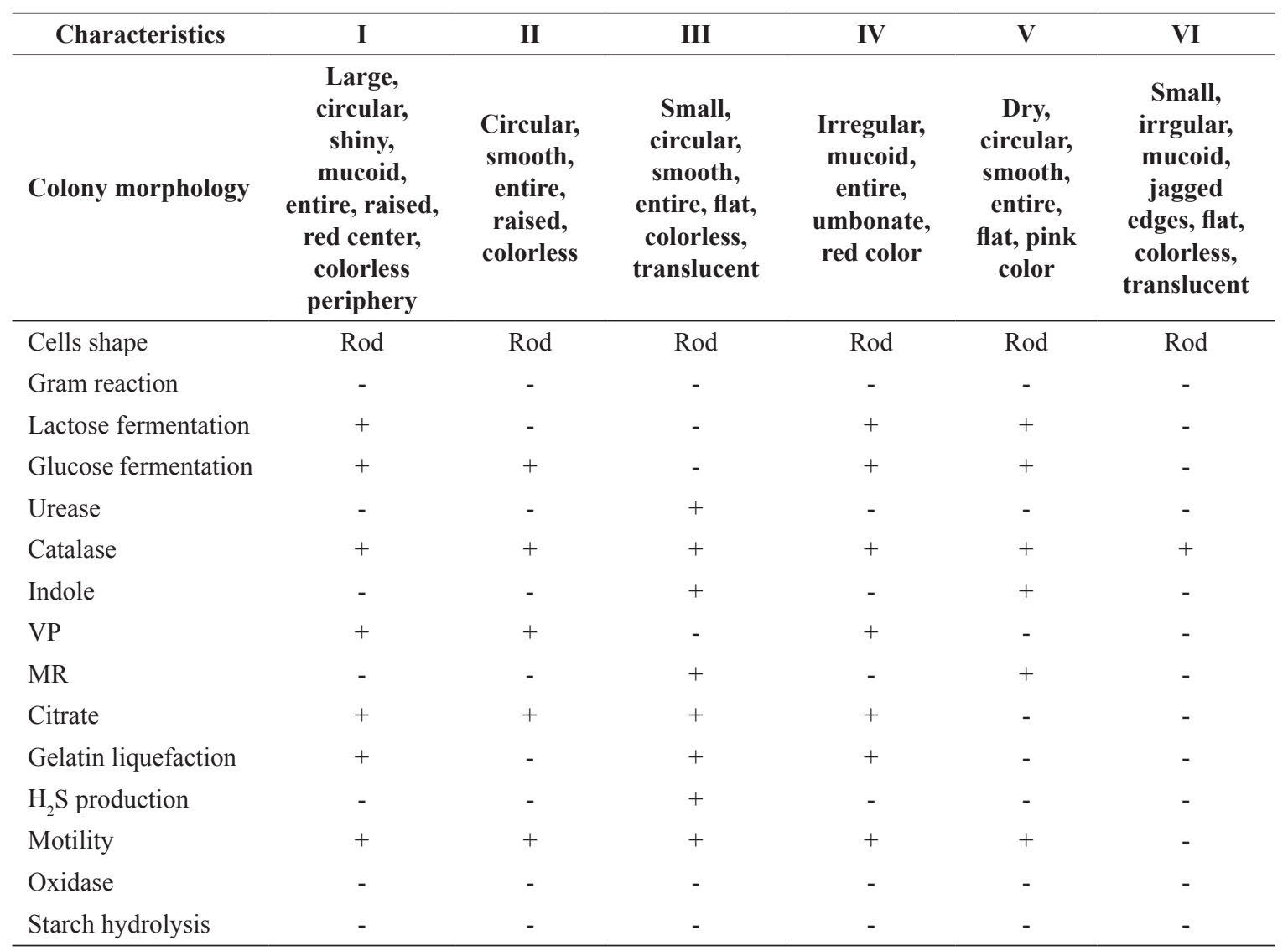




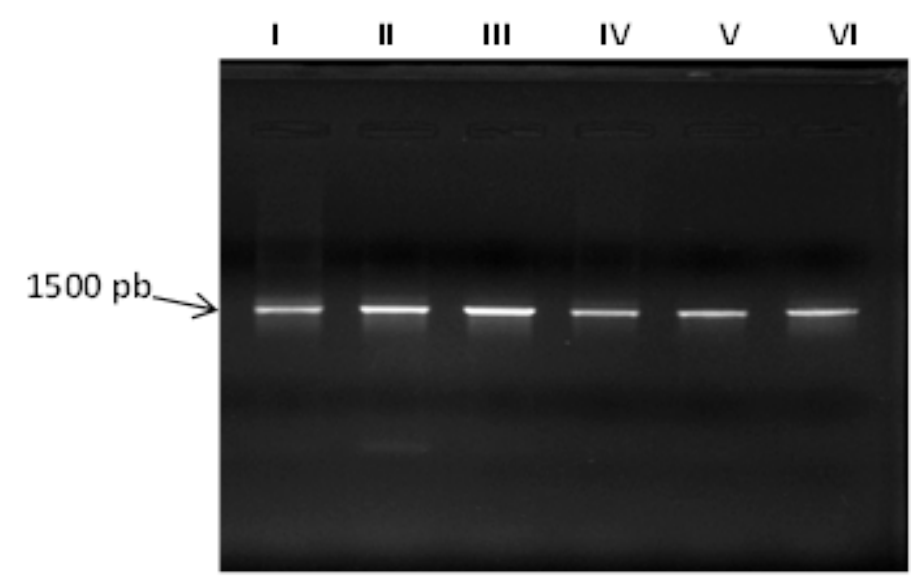

Fig. 1. PCR gel electrophoresis showing 16S rRNA gene bands (at 1500pb) of the isolated bacterial groups.

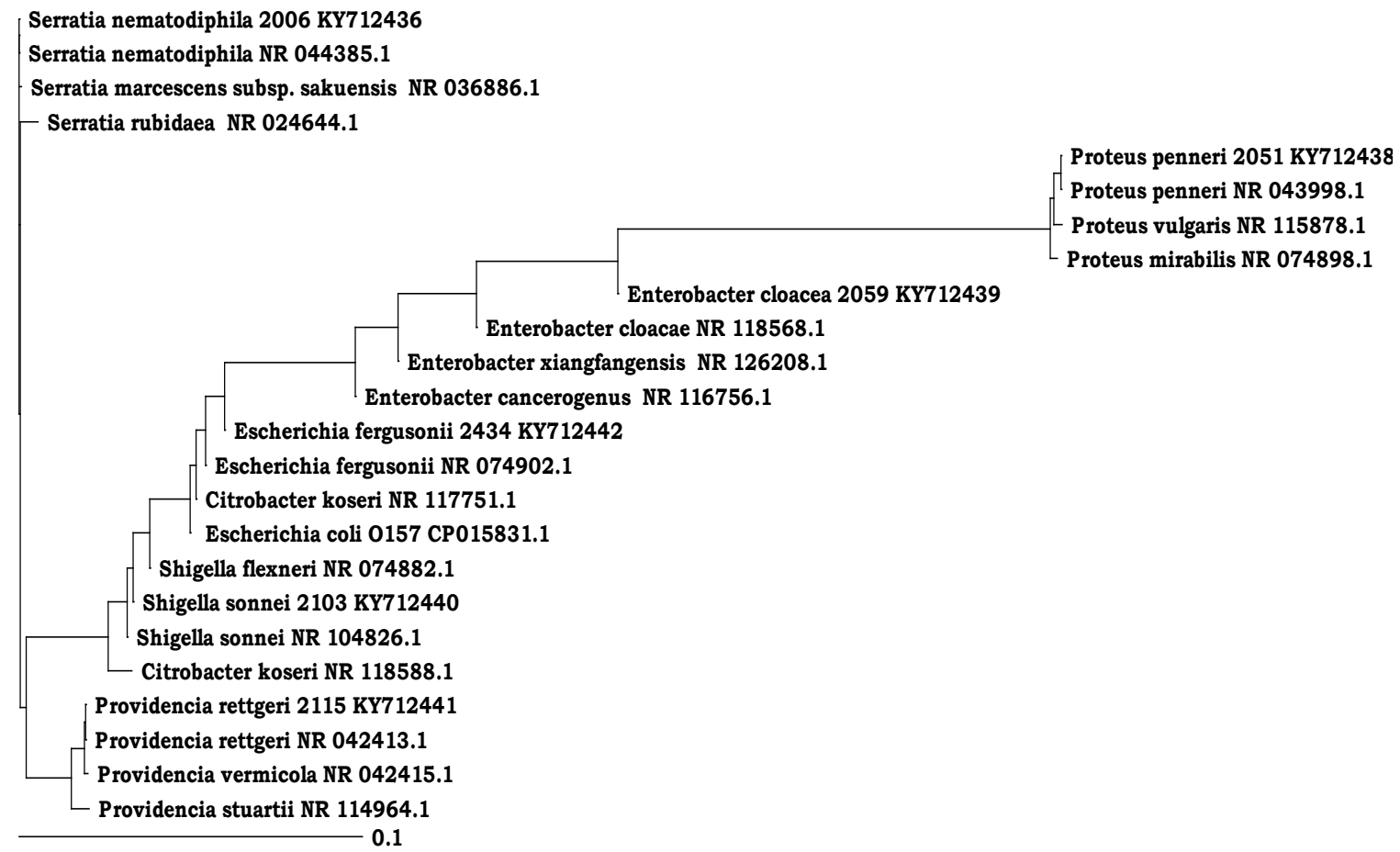

Fig. 2. The phylogenetic tree of the tested bacterial isolates based on 16S rRNA gene sequences showing their position among the related strains in GenBank database.

The total bacterial count ranged from $24 \pm 1.7 \times 10^{5}$ to $291 \pm 2.15 \times 10^{5}$ of the collected fresh ground beef samples. However, the count recoreded on the MAC medium revealed that the most dominant species was Enterobacter cloacea and Providencia rettgeri with frequency of $85 \%$ and $55 \%$, respectively (Table 2). While, the frequency of Proteus penneri, Serratia nematodiphila, Escherichia fergusonii and Shigella sonnei were 35, 20, 20 and $10 \%$, respectively. The heavy load of the Enterobacteriaceae members in the collected ground beef might be due to its available nutrients such as amino acids, minerals, vitamins, water and fats (Ferraz et al., 2010). Ground beef contamination by spoilage bacteria may be resulted from food processing equipment and meat handlers (Schroeder et al., 2004). The combination of meat tissues from different animals is also one of the reasons for ground beef contamination (LeJeune \& Christie, 2004).

Antibacterial activity of spices against the isolated enteric bacteria

Seven spices were tested include clove 
(Syzygium aromaticum), thyme (Thymus vulgaris), cinnamon (Cinnamomum verum), ginger (Zingiber officinale), anise (Pimpinella anisum), red pepper (Capsicum annuam) and curry (Murraya koenigii) for their antibacterial effect on the recovered bacteria from ground beef. The results in Table 3 show that the clove aqueous extract was the most potent antibacterial with an inhibition zone diameter of $24.5 \pm 0.6,22 \pm 0.28$, $14.5 \pm 0.29,22.5 \pm 0.29,15.5 \pm 0.29$ and $22.5 \pm 0.29$ $\mathrm{mm}$ against Enterobacter cloacea, Providencia rettgeri, Serratia nematodiphilia, Escherichia fergusonii, Proteus penneri and Shigella sonnei, respectively. Several studies indicated that spices had a deleterious effect on foodborne bacteria (Gutierrez et al., 2009; Škrinjar \& Nemet, 2009; Tajkarimi et al., 2010 and Ahene et al., 2011).
Zhang et al. (2009) found that the clove extract has a strong antibacterial activity against the four common meat spoilage and pathogenic bacteria; Listeria monocytogenes, Escherichia coli, Pseudomonas fluorescens and Lactobacillus sake. Cloves are aromatic herbs and have pleasant yet spicy. They are the flowering bud of the tree Eugenia aromatic, which dried and become brown and used for medicinal purposes (Beuchat, 2000). Clove is effective against different bacterial species such as Escherichia coli, Salmonella enteric and Staphylococcus aureus (Beuchat, 2000 and Cressy et al., 2003). It has also antifungal, anticarcinogenic, antiallergic, antimutagenic, antioxidant and insecticidal properties (Ogata et al., 2000; Friedman et al., 2002; Tworkoski, 2002 and Park \& Shin, 2005).

TABLE 2. Colony forming units (CFU) and frequency (\% out of 20 samples) of the isolated bacteria from the collected meat samples.

\begin{tabular}{|c|c|c|c|c|c|c|c|}
\hline \multirow{3}{*}{$\begin{array}{l}\text { Meat } \\
\text { samples }\end{array}$} & \multirow{3}{*}{$\begin{array}{l}\text { Nutrient } \\
\text { agar }\end{array}$} & \multicolumn{6}{|c|}{ CFUx10 $10^{5}$} \\
\hline & & \multicolumn{6}{|c|}{ MacConkey agar } \\
\hline & & $\begin{array}{c}\text { Enterobacter } \\
\text { cloacea }\end{array}$ & $\begin{array}{l}\text { Providencia } \\
\text { rettgeri }\end{array}$ & $\begin{array}{l}\text { Proteus } \\
\text { penneri }\end{array}$ & $\begin{array}{c}\text { Serratia } \\
\text { nematodiphila }\end{array}$ & $\begin{array}{c}\text { Escherichia } \\
\text { fergusonii }\end{array}$ & $\begin{array}{c}\text { Shigella } \\
\text { sonnei }\end{array}$ \\
\hline 1 & $49 \pm 1.15$ & $19 \pm 0.57$ & $10 \pm 1.2$ & - & - & - & - \\
\hline 2 & $321 \pm 2.3$ & $8 \pm 1.3$ & $13 \pm 0.68$ & $8 \pm 0.68$ & - & - & - \\
\hline 3 & $291 \pm 2.15$ & $14 \pm 1.7$ & - & $26 \pm 1.15$ & - & $3 \pm 0.68$ & $23 \pm 1.7$ \\
\hline 4 & $117 \pm 2.15$ & $5 \pm 0.57$ & - & $4 \pm 0.68$ & $5 \pm 0.7$ & $6 \pm 1.15$ & - \\
\hline 5 & $24 \pm 1.7$ & - & - & - & - & - & $23 \pm 1.2$ \\
\hline 6 & $74 \pm 2.5$ & $16 \pm 2.5$ & - & - & - & $58 \pm 1.3$ & - \\
\hline 7 & $166 \pm 1.15$ & $18 \pm 2.1$ & $24 \pm 1.5$ & - & $40 \pm 1.2$ & - & - \\
\hline 8 & $144 \pm 2.15$ & - & - & - & $51 \pm 1.3$ & - & - \\
\hline 9 & $87 \pm 1.15$ & $24 \pm 1.15$ & $19 \pm 1.15$ & - & - & - & - \\
\hline 10 & $61 \pm 0.58$ & $31 \pm 0.57$ & $21 \pm 1.15$ & - & - & - & - \\
\hline 11 & $218 \pm 1.15$ & $90 \pm 1.7$ & - & $16 \pm 1.7$ & - & - & - \\
\hline 12 & $94 \pm 0.57$ & $23 \pm 1.3$ & $66 \pm 2.5$ & $41 \pm 1.7$ & $2 \pm 0.68$ & - & - \\
\hline 13 & $234 \pm 1.33$ & $104 \pm 1.15$ & - & - & - & - & - \\
\hline 14 & $128 \pm 1.15$ & - & $63 \pm 1.3$ & $64 \pm 1.15$ & - & - & - \\
\hline 15 & $163 \pm 1.7$ & $19 \pm 0.3$ & $61 \pm 1.15$ & - & - & - & - \\
\hline 16 & $82 \pm 1.7$ & $67 \pm 1.15$ & - & - & - & - & - \\
\hline 17 & $46 \pm 0.86$ & $18 \pm 1.7$ & - & $14 \pm 1.7$ & - & $13 \pm 1.2$ & - \\
\hline 18 & $60 \pm 1.15$ & $17 \pm 1.15$ & $16 \pm 0.58$ & - & - & - & - \\
\hline 19 & $78 \pm 1.15$ & $17 \pm 1.3$ & $20 \pm 1.3$ & - & - & - & - \\
\hline 20 & $213 \pm 1.15$ & $46 \pm 1.5$ & $4 \pm 0.3$ & - & - & - & - \\
\hline $\begin{array}{l}\text { Total } \\
\left(\mathrm{x} 10^{5}\right)\end{array}$ & 2610 & 248 & 83 & 17 & 67 & 151 & 81 \\
\hline Frequency & o out of 20) & 85 & 55 & 35 & 20 & 20 & 10 \\
\hline
\end{tabular}


TABLE 3. Antibacterial activity of the aqueous extracts of the tested spices against the isolated bacteria.

\begin{tabular}{lcccccc}
\hline \multirow{2}{*}{ Spices } & \multicolumn{5}{c}{ Diameter inhibition zone of (mm) } \\
\cline { 2 - 7 } & $\begin{array}{c}\text { Enterobacter } \\
\text { cloacea }\end{array}$ & $\begin{array}{c}\text { Providencia } \\
\text { rettgeri }\end{array}$ & $\begin{array}{c}\text { Serratzia } \\
\text { nematodiphilia }\end{array}$ & $\begin{array}{c}\text { Escherichia } \\
\text { fergusonii }\end{array}$ & $\begin{array}{c}\text { Proteus } \\
\text { penneri }\end{array}$ & $\begin{array}{c}\text { Shigella } \\
\text { sonnei }\end{array}$ \\
\hline Clove & $24.5 \pm 0.6$ & $22 \pm 0.28$ & $14.5 \pm 0.29$ & $22.5 \pm 0.29$ & $15.5 \pm 0.29$ & $22.5 \pm 0.29$ \\
Thyme & $20.5 \pm 0.86$ & $13.5 \pm 0.12$ & - & $15 \pm 0.86$ & - & - \\
Red pepper & $17 \pm 0.29$ & - & - & $18.5 \pm 0.29$ & - & - \\
Cinnamon & - & - & $21 \pm 0.57$ & - & $17 \pm 0.87$ & $19.5 \pm 0.29$ \\
Anise & - & - & $13.5 \pm 0.28$ & - & $14.5 \pm 0.57$ & $20 \pm 0.28$ \\
Curry & - & $20.5 \pm 0.29$ & $15.5 \pm 1.15$ & - & $16.5 \pm 0.57$ & - \\
Ginger & - & - & $16 \pm 0.28$ & - & $15.5 \pm 0.28$ & - \\
\hline
\end{tabular}

Both of cinnamon and anise extract had a harmful effect on the growth of Serratia nematodiphilia, Proteus penneri and Shigella sonnei. Also, the thyme extract exhibit inhibitory effect on Enterobacter cloacea, Providencia rettgeri and Escherichia fergusonii. The red pepper extract was effective in reducing the growth of Enterobacter cloacea and Escherichia fergusonii with an inhibition zone diameter of $17 \pm 0.29$ and $18.5 \pm 0.29 \mathrm{~mm}$, respectively. Ginger had a moderate antibacterial effect on growth of Serratia nematodiphila and Proteus penneri with an inhibition zone diameter of $16 \pm 0.28$ and15.5 \pm $0.28 \mathrm{~mm}$, respectively. It is well documented that showed that ginger had no any antibacterial effect on the growth of the tested bacteria (Keskin \& Toroglu, 2011 and Akrayi, 2014). In a study by Škrinjar \& Nemet (2009), thyme has a potent antibacterial effect on Enterbacter cloaceae and Listeria spp. Asimi et al. (2013) showed that cinnamon was the most vigorous antibacterial against the tested bacterial strains.

Antibacterial activity of different solvent extracts of clove against the isolated enteric bacteria

Clove was extracted by the different solvents such as ethanol, ethyl-acetate, acetone and chloroform and the results were recorded in Table 4. All the extracts of the different solvents have antibacterial activity against all the tested bacteria with different inhibition zone diameters. Witkowska et al.(2013) reported that the choice of the solvent used to extract the spices has an influence on the antimicrobial activity. The ethyl-acetate extract was the most effective with the lowest MIC against most of the tested species as shown in Table 5. The lowest MIC of ethyl-acetate extract was $2.5 \mathrm{mg} / \mathrm{ml}$ against Escherichia fergusonii while the lowest MIC of acetone extract was $5 \mathrm{mg} / \mathrm{ml}$ against Enterobacter cloacea and the lowest MIC of chloroform extract was $250 \mathrm{mg} / \mathrm{ml}$ against Proteus penneri. On the other hand, the lowest MIC of the clove aqueous extract was $150 \mathrm{mg} / \mathrm{ml}$ with Enterobacter cloacea. The antibacterial activity of spices could be attributed to the presence of antioxidant compounds (Sebranek et al., 2005).

GC-MS analysis of ethyl-acetate extract of clove

The obtained GC-MS analysis chromatogram (Fig. 3) of the ethyl-acetate extract of clove indicatedthat the major constituent components were eugenol $\left(\mathrm{C}_{10} \mathrm{H}_{12} \mathrm{O}_{2}\right)$, Phenol,2methoxy-4-(2-propenyl)-acetate $\quad\left(\mathrm{C}_{12} \mathrm{H}_{14} \mathrm{O}_{3}\right)$, trans-Caryophylene $\left(\mathrm{C}_{15} \mathrm{H}_{24}\right), \quad$ 4-Allyl-2methoxyphenoxy(trimethylsilane) $\left(\mathrm{C}_{13} \mathrm{H}_{20} \mathrm{O}_{2} \mathrm{Si}\right.$ ), Humulene $\left(\mathrm{C}_{15} \mathrm{H}_{24}\right)$ and 3-Methyl-2,5,6trimethoxy-1-indanone $\left(\mathrm{C}_{13} \mathrm{H}_{16} \mathrm{O}_{4}\right)$ with 23.18, $28.56,4.55,2.74,1.21$ and $0.01 \%$, respectively (Table 6). According to Juliani et al. (2002), the content of the clove bud essential oil was eugenol $74.4 \%, \quad \beta$-caryophyllene $7.5 \%$ and eugenyl acetate $15.8 \%$. Also, Fichi et al. (2007) reported that the clove extract contained eugenol 59.3\%, $\beta$-caryophyllene $24.9 \%$ and eugenyl acetate $4.2 \%$. Razafimamonjison et al. (2014) found that the major componentsof clove extract were eugenol, $\beta$-caryophyllene and humulene. These findings indicate that the antibacterial activity of clove spice might be due to the presence of the phenolic compounds especially the eugenol, $\beta$-caryophyllene and humulene compounds. 
TABLE 4. Antibacterial activity of different solvents extracts of clove against the isolated enteric bacteria.

\begin{tabular}{lcccc}
\hline \multirow{2}{*}{ Bacterial species } & \multicolumn{3}{c}{ Diameter inhibition zone of (mm) } \\
\cline { 2 - 5 } & Ethanol & Chloroform & Ethyl-acetate & Acetone \\
\hline Providencia rettgeri & $21 \pm 0.57$ & $9 \pm 0.57$ & $16.5 \pm 0.88$ & $24 \pm 0.57$ \\
Enterobacter cloacea & $32.5 \pm 1.0$ & $38.5 \pm 3.5$ & $40.5 \pm 0.57$ & $33 \pm 0.88$ \\
Serratia nematodiphilia & $21.5 \pm 0.57$ & $17 \pm 0.17$ & $21 \pm 0.57$ & $21 \pm 0.67$ \\
Escherichia fergusonii & $29 \pm 0.57$ & $36.5 \pm 0.33$ & $30.5 \pm 0.33$ & $25 \pm 0.57$ \\
Proteus penneri & $21 \pm 0.28$ & $19.5 \pm 0.16$ & $20 \pm 0.33$ & $20.5 \pm 0.33$ \\
Shigella sonnei & $19.5 \pm 0.33$ & $11 \pm 0.57$ & $13.5 \pm 0.44$ & $21 \pm 0.17$ \\
\hline
\end{tabular}

TABLE 5. MIC of clove using different solvent for the six groups.

\begin{tabular}{lccccc}
\hline \multirow{2}{*}{ Bacterial isolates } & \multicolumn{5}{c}{ MIC (mg/ml) of clove extracts } \\
\cline { 2 - 5 } & Water & Ethanol & Acetone & Chloroform & Ethyl acetate \\
\hline Providencia rettgeri & 500 & 500 & 500 & 500 & 150 \\
Proteus penneri & 500 & 5 & 150 & 250 & 50 \\
Serratia nematodiphila & 500 & 500 & 500 & 500 & 500 \\
Shigella sonnei & 500 & 500 & 500 & 500 & 50 \\
Escherichia fergusonii & 500 & 250 & 500 & 500 & 2.5 \\
Enterobacter cloacea & 150 & 500 & 5 & 500 & 150 \\
\hline
\end{tabular}

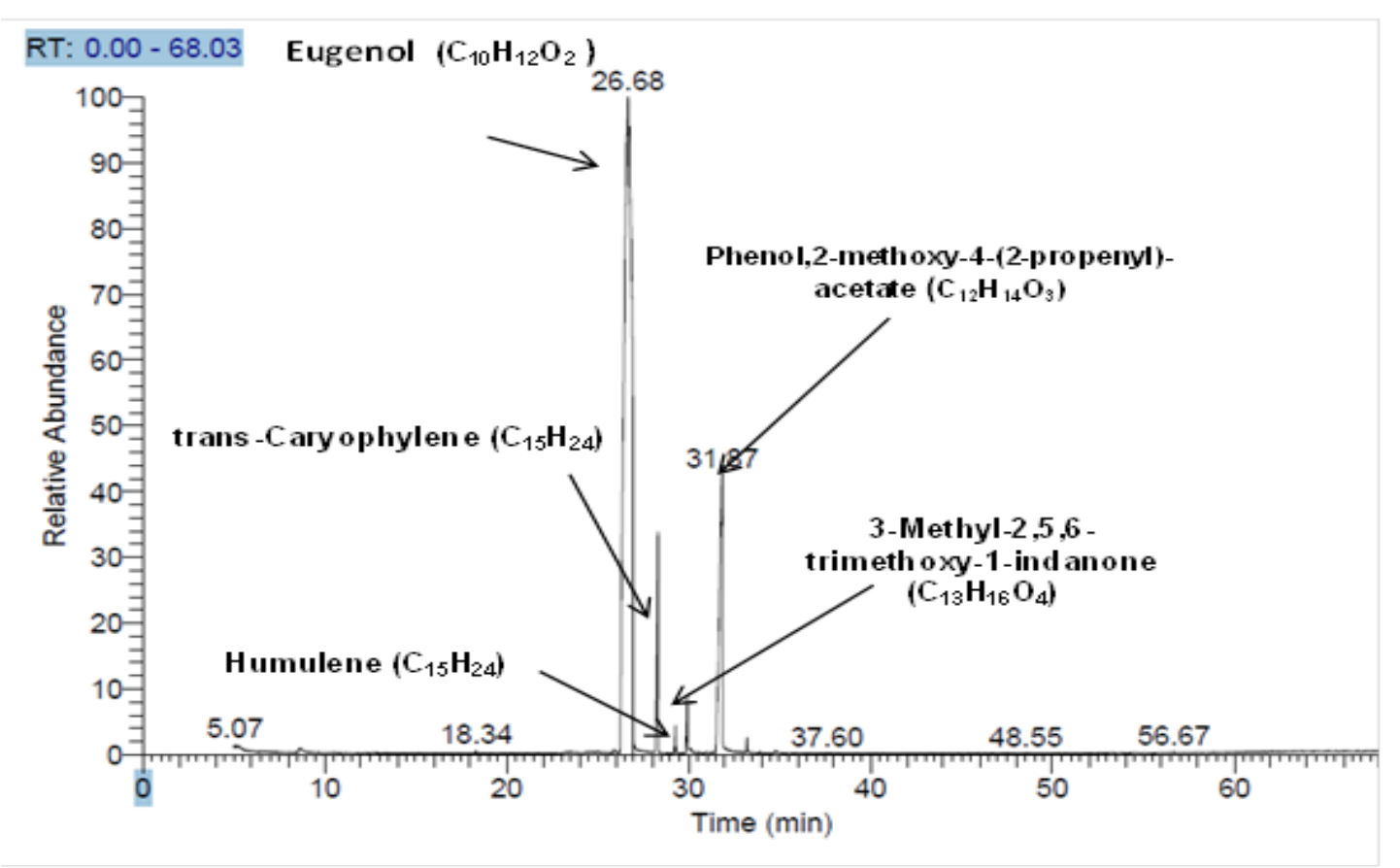

Fig. 3. GC-MS analysis of the ethyl acetate extract of clove. 
TABLE 6. GC-MS analysis of the ethyl acetate extract of clove.

\begin{tabular}{|c|c|c|c|c|c|c|}
\hline Peak & RT & Area\% & MW & MF & Compound & Structure \\
\hline 1 & 26.68 & 23.18 & 164 & $\mathrm{C}_{10} \mathrm{H}_{12} \mathrm{O}_{2}$ & Eugenol & \\
\hline 2 & 28.32 & 4.55 & 204 & $\mathrm{C}_{15} \mathrm{H}_{24}$ & trans-Caryophylene & \\
\hline 3 & 29.28 & 1.21 & 204 & $\mathrm{C}_{15} \mathrm{H}_{24}$ & Humulene & \\
\hline 4 & 29.92 & 2.74 & 236 & $\mathrm{C}_{13} \mathrm{H}_{20} \mathrm{O}_{2} \mathrm{Si}$ & $\begin{array}{l}\text { (4-Allyl-2- } \\
\text { methoxyphenoxy) } \\
\text { trimethylsilane }\end{array}$ & \\
\hline 5 & 30.15 & 0.01 & 236 & $\mathrm{C}_{13} \mathrm{H}_{16} \mathrm{O}_{4}$ & $\begin{array}{l}3 \text { - M e t h y } 1-2,5,6- \\
\text { trimethoxy-1-indanone }\end{array}$ & \\
\hline 6 & 31.85 & 28.56 & 206 & $\mathrm{C}_{12} \mathrm{H}_{14} \mathrm{O}_{3}$ & $\begin{array}{l}\text { Phenol,2-methoxy-4-(2- } \\
\text { propenyl)-,acetate (CAS) }\end{array}$ & \\
\hline
\end{tabular}

RT: Retention time, MW: Molecular weight, MF: Molecule formula.

\section{Conclusion}

Ground beef is heavily contaminated by different members of Enterobacteriaceae such as Serratia nematodiphila, Proteus penneri, Shigella sonnei, Providencia rettgeri, Escherichia fergusonii and Enterobacter cloacea. These bacterial species represent a harmful effect on food safety and the health of the consumer. Many natural spices are cheap and effective antibacterial against the foodborne pathogens and can be used widely instead of chemical additives in food processing. It is worth mentioning that the most active antibacterial spice is the clove due to the presence of the phenolic compounds B-caryophylene, humulene and eugenol in its chemical composition.

\section{References}

Addis, M. and Sisay, D. (2015) A review on major food borne bacterial illnesses. Journal of Tropical Diseases and Public Health, 3, 1-7.

Adwan, G., Alqarem, B. and Adwan, K. (2015) Prevalence of foodborne pathogens in meat samples in Palestine. International Food Research Journal, 22(5), 1806-1812.

Ahene, R., Odamtten, G. and Owusu, E. (2011) Fungal and bacterial contaminants of six spices and spice products in Ghana. African Journal of Environmental Science and Technology, 5, 633640.

Ahmed, S.A. and Sarangi, S. (2013) Analysis of bacterial contamination in fresh and finished meat products and their molecular identification. International Journal of Pharmaceutical Science Invention, 2(7), 27-32. 
Akrayi, H.F. (2014) Antibacterial effect of aqueous extracts of spices and herbs against bacteria isolated from frozen meat. Medical Journal of Islamic World Academy of Sciences, 22, 30-35.

Asimi, O.A., Sahu, N. and Pal, A. (2013) Antioxidant activity and antimicrobial property of some Indian spices. International Journal of Scientific and Research Publications, 3(3), 541.

Becker, B., Weiss, C. and Holzapfel, W.H. (2009) An evaluation of the use of three phenotypic test-systems for biochemical identification of Enterobacteriaceae and Pseudomonadaceae. Food Control, 20, 815-821.

Beuchat, L.R. (2000) "Control of Foodborne Pathogens and Spoilage Microorganisms by Naturally Occurring Antimicrobials". CRC Press: Boca Raton, FL.

Burt, S. (2004) Essential oils: Their antibacterial properties and potential applications in foods. A review. International Journal of Food Microbiology, 94, 223-253.

Chikwendu, C., Nwabueze, R. and Anyanwu, B. (2008) Antibiotic resistance profile of Escherichia coli from clinically healthy pigs and their commercial farm environments. African Journal of Microbiology Research, 2, 12-17.

Cressy, H.K., Jerrett, A.R., Osborne, C.M. and Bremer, P.J. (2003) A novel method for the reduction of numbers of Listeria monocytogenes cells by freezing in combination with an essential oil in bacteriological media. Journal of food Protection, 66, 390-395.

Desmond, E. (2006) Reducing salt: A challenge for the meat industry. Meat Science, 74, 188-196.

Doulgeraki, A.I., Paramithiotis, S. and Nychas, G-JE (2011) Characterization of the Enterobacteriaceae community that developed during storage of minced beef under aerobic or modified atmosphere packaging conditions. International Journal of Food Microbiology, 145, 77-83.

Ercolini, D., Russo, F., Torrieri, E., Masi, P. and Villani, F. (2006) Changes in the spoilage-related microbiota of beef during refrigerated storage under different packaging conditions. Applied and Environmental Microbiology, 72, 4663-4671.
Ferraz, M.A., Cerqueira, M.M. and Souza, M.R. (2010) Evaluation of Enterobacteriaceae in the powdered milk production chain using both traditional (ISO 21528: 2) and rapid (3M $\mathrm{M}^{\mathrm{TM}}$ Petrifilm ${ }^{\mathrm{TM}}$ ) methods. Annals of Microbiology, 60, 373-376.

Fichi, G., Flamini, G., Giovanelli, F., Otranto, D. and Perrucci, S. (2007) Efficacy of an essential oil of Eugenia caryophyllata against Psoroptes cuniculi. Experimental Parasitology, 115, 168-172.

Friedman, M., Henika, P.R. and Mandrell, R.E. (2002) Bactericidal activities of plant essential oils and some of their isolated constituents against Campylobacter jejuni, Escherichia coli, Listeria monocytogenes and Salmonella enterica. Journal of Food Protection, 65, 1545-1560.

Gottardi, D., Bukvicki, D., Prasad, S. and Tyagi, A.K. (2016) Beneficial effects of spices in food preservation and safety. Frontiers in Microbiology, 7, 1394.

Gutierrez, J., Barry-Ryan, C. and Bourke, P. (2009) Antimicrobial activity of plant essential oils using food model media: Efficacy, synergistic potential and interactions with food components. Food Microbiology, 26, 142-150.

Gwida, M., Hotzel, H., Geue, L. and Tomaso, H. (2014) Occurrence of Enterobacteriaceae in raw meat and in human samples from Egyptian retail sellers. International Scholarly Research Notices, 2014.

Höll, L., Behr, J. and Vogel, R.F. (2016) Identification and growth dynamics of meat spoilage microorganisms in modified atmosphere packaged poultry meat by MALDI-TOF MS. Food Microbiology, 60, 84-91.

Joosten, H., Marugg, J., Stephan, R., Klijn, A., Jackson, T. and Iversen, C. (2008) A rapid and reliable alternative to ISO 21528-1: 2004 for detection of Enterobacteriaceae. International Journal of Food Microbiology, 125, 344-346.

Juliani, H., Simon, J.E., Ramboatiana, M.R., Behra, O., Garvey, A. and Raskin, I. (2002) Malagasy aromatic plants: Essential oils, antioxidant and antimicrobial activities. The Future for Medicinal and Aromatic Plants, 629, 77-81.

Karlowsky, J.A., Jones, M.E., Thornsberry, 
C., Friedland, I.R. and Sahm, D.F. (2003) Trends in antimicrobial susceptibilities among Enterobacteriaceae isolated from hospitalized patients in the United States from 1998 to 2001. Antimicrobial Agents and Chemotherapy, 47, 1672-1680.

Keskin, D. and Toroglu, S. (2011) Studies on antimicrobial activities of solvent extracts of different spices. Journal of Environmental Biology, 32, 251-256.

Kiessling, C.R., Cutting, J.H., Loftis, M., Kiessling, W.M., Datta, A.R. and Sofos, J.N. (2002) Antimicrobial resistance of food-related Salmonella isolates, 1999-2000. Journal of Food Protection, 65, 603-608.

Kwon, H.A., Kwon, Y-J, Kwon, D-Y and Lee. J.H. (2008) Evaluation of antibacterial effects of a combination of Coptidis Rhizoma, Mume Fructus, and Schizandrae Fructus against Salmonella. International Journal of Food Microbiology, 127, 180-183.

LeJeune, J.T. and Christie, N.P. (2004) Microbiological quality of ground beef from conventionally-reared cattle and "raised without antibiotics" label claims. Journal of Food Protection, 67, 1433-1437.

Ogata, M., Hoshi, M., Urano, S. and Endo, T. (2000) Antioxidant activity of eugenol and related monomeric and dimeric compounds. Chemical and Pharmaceutical Bulletin, 48,1467-1469.

Park, I-K and Shin, S-C (2005) Fumigant activity of plant essential oils and components from garlic (Allium sativum) and clove bud (Eugenia caryophyllata) oils against the Japanese termite (Reticulitermes speratus Kolbe). Journal of Agricultural and Food Chemistry, 53, 4388-4392.

Paterson, D.L. (2006) Resistance in Gram-negative bacteria: Enterobacteriaceae. American Journal of Infection Control, 34, S20-S28.

Rasmey, A-H.M., Desoki, S.G. and Deabes, M. (2018) Isolation, characterization and antibiotics susceptibility of glucuronidase producing Escherichia coli and other enteric bacteria from ground beef. African Journal of Biotechnology, 17, 29-36.

Razafimamonjison, G., Jahiel, M., Duclos, T.,
Ramanoelina, P., Fawbush, F. and Danthu, P. (2014) Bud, leaf and stem essential oil composition of Syzygium aromaticum from Madagascar, Indonesia and Zanzibar. International Journal of Basic and Applied Sciences, 3, 224.

Sanger, F., Nicklen, S. and Coulson, A.R. (1977) DNA sequencing with chain-terminating inhibitors. Proceedings of the National Academy of Sciences, 74(12), 5463-5467.

Schroeder, C.M., White, D.G. and Meng, J. (2004) Retail meat and poultry as a reservoir of antimicrobial-resistant Escherichia coli. Food Microbiology, 21, 249-255.

Sebranek, J., Sewalt, V., Robbins, K. and Houser, T. (2005) Comparison of a natural rosemary extract and BHA/BHT for relative antioxidant effectiveness in pork sausage. Meat Science, 69, 289-296.

Sethi, S., Dutta, A., Gupta, B.L. and Gupta, S. (2013) Antimicrobial activity of spices against isolated food borne pathogens. International Journal of Pharmacy and Pharmaceutical Sciences, 5, 260262.

Sharma, S. (2015) Food preservatives and their harmful effects. International Journal of Scientific and Research Publications, 5, 1-2.

Škrinjar, M.M. and Nemet, N.T. (2009) Antimicrobial effects of spices and herbs essential oils. Acta Periodica Technologica, 40, 195-209.

Tajkarimi, M., Ibrahim, S.A. and Cliver, D. (2010) Antimicrobial herb and spice compounds in food. Food Control, 21, 1199-1218.

Thanigaivel, G. and Anandhan, A.S. (2015) Isolation and characterization of microorganisms from raw meat obtained from different market places in and around Chennai. Journal of Pharmaceutical, Chemical and Biological Sciences, 3, 295-301.

Tworkoski T (2002) Herbicide effects of essential oils. Weed science 50, 425-431.

Witkowska, A.M., Hickey, D.K., Alonso-Gomez, M. and Wilkinson, M. (2013) Evaluation of antimicrobial activities of commercial herb and spice extracts against selected food-borne bacteria. Journal of Food Research, 2, 37. 
Zhang, H., Kong, B., Xiong, Y.L. and Sun, X. (2009) Antimicrobial activities of spice extracts against pathogenic and spoilage bacteria in modified atmosphere packaged fresh pork and vacuum packaged ham slices stored at 4 C. Meat Science, 81, 686-692. on the production of staphylococcal enterotoxin I from Staphylococcus aureus isolate. Journal of Food Quality, 2017, 1-6.

Zhao, Y., Zhu, A., Tang, J., Tang, C. and Chen, J. (2017) Comparative effects of food preservatives

\section{النشاط الحيوي للقرنفل (سبزيجيم اروماتبكم) ضد بعض الأصناف من عائلة البكتيريا المعوية

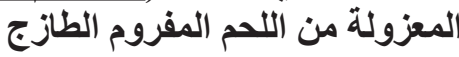

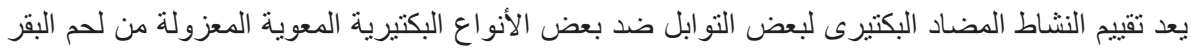

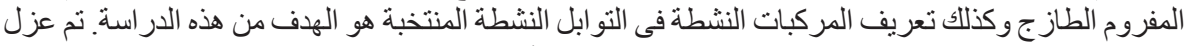

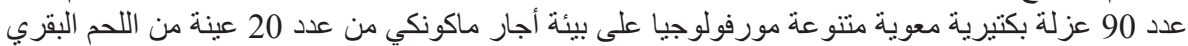

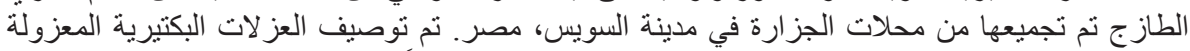

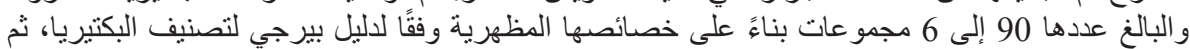

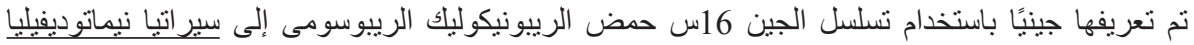

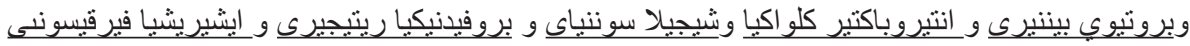

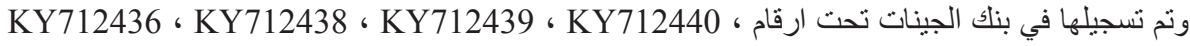

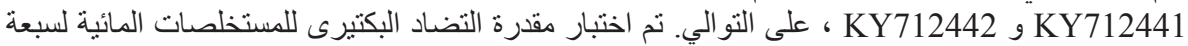

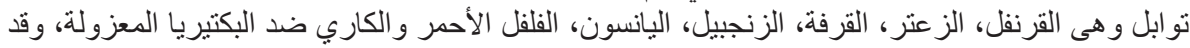

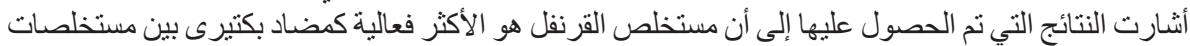

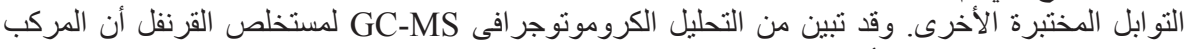
الفعال بهذا المستخلص هو الأوجينول. 